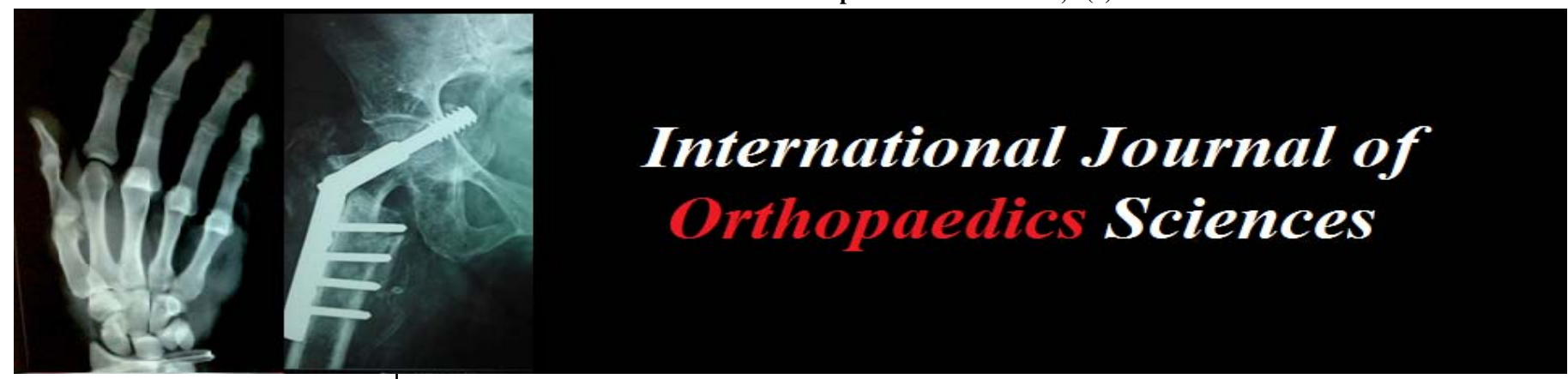

ISSN: $2395-1958$

IJOS 2018; 4(3): 414-418

(C) 2018 IJOS

www.orthopaper.com

Received: 14-07-2018

Accepted: 15-08-2018

Dr. Mohammed Abdul Bari

Assistant Professor, Department of Orthopedics, Mamata Medical

College, Khammam, Telangana, India

Dr. Sanjeev Chincholi

Professor of Orthopaedics,

Mamata Medical College,

Khammam, Telangana, India

\section{Surgical management of diaphyseal fractures of tibia with intramedullary interlocking nailing in adult patients}

\section{Dr. Mohammed Abdul Bari and Dr. Sanjeev Chincholi}

DOI: https://doi.org/10.22271/ortho.2018.v4.i3h.73

\section{Abstract}

Background and Objectives: Fracture shaft of tibia are increasing due to high velocity trauma and industrialization. Not only are they common but often difficult to treat. Previously surgeons had to rely on non operative methods, 'V' nailing, 'plates and Screws' and external fixators but they had their known drawbacks like prolonged immobilization, infection, delayed union, nonunion, malunion and cumbersome for patients, with the introduction of intramedullary interlocking nail for tibial shaft fractures has overcome some of these complications and encourages the patients for early mobilization. This study has been done to evaluate the functional results and complications of intramedullary interlocking nail for tibial diaphyseal fractures of closed type.

Methods: Fifty adult patients with fresh tibial shaft fractures were treated surgically with intramedullary interlocking nail between December 2014 to march 2016.

Results: Among fifty patients treated with intramedullary interlocking nail, fractures united with a union rate of $94 \%$. Two fractures showed delayed union, one fractures had non union and one fracture had malunion. One case had distal locking screws breakage. Two cases of superficial infection were noted. Seven patients had anterior knee pain, one case developed shortening of leg which was less than $1 \mathrm{~cm}$. Functional results were graded according to the criteria by Klemm and Borner. 92\% of patients achieved good or excellent results, fair results were obtained in one patient and in one patient the functional results were poor.

Conclusion: This study with fresh fractures of the tibia (closed type, transverse and short oblique) treated with intramedullary interlocking nailing is a safe and effective technique for management of closed tibial diaphyseal fractures with high union rates, low incidence of complication. Good functional results are achieved by careful preoperative planning and respecting the principles of intramedullary interlocking nailing technique.

Keywords: Fracture tibia, closed type, Intramedullay interlocking nailing

\section{Introduction}

Tibia is the most commonly fractured long bone and the exposed anatomical location makes it vulnerable to direct blow and high energy trauma as a result of motor vehicle accident. Tibia has precarious blood supply due to inadequate muscular envelope. Tibial fractures may be associated with compartment syndrome, vascular or neural injury. The presence of hinge joints at the knee and the ankle, allows no adjustment for rotatory deformity after fracture. Because of high incidence of complications, management often is difficult.

Various modalities of treatment of fracture shaft of tibia are conservative gentle manipulation and use of short leg or long leg cast, open reduction and internal fixation with plates and screws, external fixation and intramedullary fixation with flexible nails (ender pins) and interlocking intramedullary nails with or without reaming. Closed intramedullary interlocking nailing is accepted by most of the orthopaedic surgeons, as the treatment of choice in diaphyseal fractures but it is also associated with a number of complications. This is a prospective study to evaluate the results of intramedullary interlocking nailing in closed diaphyseal fractures of tibia and to study the complications of intramedullary interlocking nailing of fractures shaft of tibia.

\section{Correspondence}

Dr. Sanjeev Chincholi

Professor of Orthopaedics,

Mamata Medical College,

Khammam, Telangana, India 


\section{Objectives}

- To evaluate the results of intramedullary interlocking nailing in diaphyseal fractures of tibia.

- To study the complications of intramedullary interlocking nailing of fractures shaft of tibia.

\section{Material and methodology}

A prospective study of results and complications following intramedullary interlocking nail in closed diaphyseal fracture of tibial was done from December 2014 to march 2016. 50 patients with fracture shaft of tibia were selected for the study, all the fractures were post traumatic, Age between 2060 years with transverse and short oblique closed fracture tibia shaft. The method used for fracture fixation was closed reamed intramedullary interlocking nail, the duration of follow up ranged from 10 months to 12 months.

Age less than 20 years, old fractures with complications like infections, delayed union, nonunion, mal union, compound fractures classified according to Gustillo Anderson system and tibial diaphyseal fractures treated conservatively and fixed with other fixation systems like plates and screws etc are excluded. The following protocol was observed for patients with tibial diaphyseal fractures on arrival.

1. General and systemic examination as well as local examination of the patients.

2. Thorough assessment of patient to rule out head/chest/abdominal/ spinal or pelvic.

\section{Observation and results}

Approach: All the 50 nails were inserted through a patellar tendon splitting approach.

Nail size and locking: Majority of the nails inserted was $9 \mathrm{~mm}, 8$ nails were of $10 \mathrm{~mm}$ diameter and 4 were of $8 \mathrm{~mm}$ diameter. 42 fractures were locked in static mode and 8 fractures were locked dynamically.

Table 1: Nail size

\begin{tabular}{|c|c|c|}
\hline Nail size & No. of Cases & Percentage \\
\hline $8 \mathrm{~mm}$ & 4 & 8 \\
\hline $9 \mathrm{~mm}$ & 38 & 76 \\
\hline $10 \mathrm{~mm}$ & 8 & 16 \\
\hline
\end{tabular}

Patient mobilization: All the cases were started with joint mobilization exercises on $1^{\text {st }}$ post operative day. Partial weight bearing was delayed till 6 weeks irrespective of fracture configuration. The average period of commencement of full weight bearing was 12.2 weeks.

Table 2: Patient Mobilization

\begin{tabular}{|c|c|c|}
\hline FWB & No. of Cases & Percentage \\
\hline 12 weeks & 42 & 84 \\
\hline 14 weeks & 5 & 10 \\
\hline$>14$ weeks & 3 & 6 \\
\hline
\end{tabular}

Secondary Procedure: Dynamization was done in 8 cases between 12 and 16 weeks depending on the progress of fracture healing.

Table 3: Secondary Procedure

\begin{tabular}{|c|c|c|}
\hline Procedure & No. of Cases & Percentage \\
\hline Dynamization & 8 & 16 \\
\hline
\end{tabular}

Range of motion: The average range of motion in the knee joint was 135.6 degree, full ankle motion was observed in 45 patients. Two patient showed a loss of $>25^{\circ}$ of motion at ankle compared to the normal side while 3 patients showed $<25^{0}$ of loss of joint motion.

Infection: Two patients (4\%) showed a superficial soft tissue infection.

Malunion: One case (2\%) of malunion was found with an anteroposterior angulation of 10 degrees. No case of significant rotational deformities and varus or valgus angulation deformities was noted.

Implant failure: One case (2\%) of failure of distal screws was seen in a distal third tibial fracture. It did not affect the fracture healing.

Knee pain: Twelve cases (24\%) complained of pain in the knee joint at final follow up. All were of mild variety and occurred on kneeling down.

Table 4: Complications

\begin{tabular}{|c|c|c|}
\hline Complications & No. of Cases & Percentage \\
\hline Malunion & 1 & 2 \\
\hline Superficial infection & 2 & 4 \\
\hline Knee pain & 12 & 24 \\
\hline Implant failure & 1 & 2 \\
\hline Shortening & 1 & 2 \\
\hline Non union & 1 & 2 \\
\hline Delayed union & 2 & 4 \\
\hline
\end{tabular}

\section{Functional Results}

Functional results were graded according to the criteria by Klemm and Borner ${ }^{[1]}$ (1986). $96 \%$ of patients achieved good or excellent results, fair results were obtained in one patient and in one patient, the functional results were poor. 
Table 5: Functional Results

\begin{tabular}{|c|c|c|}
\hline Functional Results & No. of Cases & Percentage \\
\hline \multicolumn{3}{|l|}{ Excellent } \\
\hline $\begin{array}{l}\text { Full knee and ankle motion } \\
\text { No muscle atrophy } \\
\text { Normal radiological alignment }\end{array}$ & 45 & 90 \\
\hline \multicolumn{3}{|l|}{ Good } \\
\hline $\begin{array}{c}\text { Slight loss of knee and ankle motion }\left(<21^{0}\right) \\
\text { Less than } 2 \mathrm{~cm} \text { of muscle atrophy } \\
\text { Angular deformity }\end{array}$ & 3 & 6 \\
\hline \multicolumn{3}{|l|}{ Fair } \\
\hline $\begin{array}{c}\text { Moderate loss of knee and ankle motion }\left(25^{0}\right) \\
\text { Morethan } 2 \mathrm{~cm} \text { of muscle atrophy } \\
\text { Angular deformity }\left(5^{0}-10^{0}\right) \\
\end{array}$ & 1 & 2 \\
\hline \multicolumn{3}{|l|}{ Poor } \\
\hline $\begin{array}{c}\text { Motion loss and knee and ankle motion }\left(>25^{\circ}\right) \\
\text { Marked muscle atrophy } \\
\text { Angular deformity }\left(>10^{\circ}\right)\end{array}$ & 1 & 2 \\
\hline
\end{tabular}

\section{Duration of surgery}

In 50 patients, 40 patients ( $80 \%$ cases) the duration of surgery was less than 90 minutes, in 8 patients (16\% cases) the duration was 91-120 minutes and in 2 patients (4\% cases) the duration was more than 120 minutes. Average operative time for all fractures was 83 minute

\section{Discussion}

The fracture fixation should be done as an emergency procedure preferably before 12 hours. The operative delay is responsible for longer post operative hospital stay, higher complication rates and increased total cost. The optimal management of soft tissue injury is the most important factor determining the outcome of open fractures of tibia. Most infections are caused by pathogens acquired in the hospital, primarily staphylococcus aureus and aerobic gram negative bacilli ${ }^{[2,3,4]}$. The spectrum of the antimicrobial regimen must include activity against gram negative bacilli and staphylococcus aureus. A third generation cephalosporin is used most often with addition of an aminoglycoside in more severe fractures. An open tibial fracture is an operative emergency. The primary treatment is early operative debridement and stabilization of the bone. The use of antibiotic regimen is a supplement to a thorough and meticulous debridement. Debridement of an open tibial fracture involves operative exploration of the wound or wounds to define the zone of injury, removal of devitalized tissues and use of pulsed lavage to achieve additional mechanical debridement of the wound ${ }^{[5,6]}$. Experience and judgement are required to determine the appropriate extent of debridement. The wound should be explored systematically to ensure complete debridement of all contaminants and devitalized tissue. If needed, patient should be taken to operation theater for repeat debridement. Most of the closed tibial fractures are unstable because of variable degree of communition and displacement. Likewise open tibial fractures by their nature tend to be unstable because of soft tissue stripping or communition or both. Rigid fixation has been shown to reduce the rate of infection, promote healing and facilitate rehabilitation of open tibial fractures ${ }^{[7]}$. There is no consensus on the best method of obtaining and maintaining alignment and stability of the tibia ${ }^{[8]}$, Closed fractures and Type I and some Type II open fractures with minimum soft tissue injuries and slight to moderate displacement of the bone can be treated with immobilization in a cast, Plate fixation provides for rigid immobilization of the fracture. But it is associated with high rate of infection, non union, implant failure and problems with wound closure ${ }^{[9]}$. Bach and Hansen ${ }^{[10]}$ reported a prevalence of infection of $35 \%$ and a prevalence of osteomyelitis of 19 percent after fixation with plaster and screws. Compared with prevalence of 13 percent and 3 percent respectively after external fixation.

Dissatisfaction with these limitations stimulated the use of intramedullary nailing in tibial shaft fractures. Velazco et al. ${ }^{[11]}$ reported the use of the lottes nail in a series of 50 open tibial fractures and noted a 6\% deep infection rate and a malunion rate of only $4 \%$. Swanson et al. ${ }^{\text {[12] }}$ compared the lottes nail with external fixation and reported infection rate of $6 \%$ in the nailing group and $7 \%$ in the external fixation group. The malunion rate was $27 \%$ and $24 \%$, respectively. The principal drawback of these nails in their limited ability to stabilize communited fracture patterns properly or those fractures that are not in proximity to the isthmus of the tibia. Locked nailing has greatly increased the scope of intramedullary fixation in the treatment of tibial fractures ${ }^{[13]}$. The success of locking nails for the treatment of closed tibia fractures stimulated their use in open tibial fractures [14]. Henley et al. [15] suggested that unreamed intramedullary interlocking nails are more efficacious than half pin external fixation, in particular with regard to maintenance of limb alignment. Reamed intramedullary interlocking nailing though has been well accepted as the treatment of choice in closed fractures, remained controversial with regard to open tibial fractures until recently. Klein et al. ${ }^{[16]}$ showed that reaming of canine tibia resulted in damage to $70 \%$ of cortical vasculature compared with $31 \%$ if an unreamed nail was used. The damage to the endosteal blood supply caused during reaming was believed to increase the infection and nonunion rates in open tibial fractures.

The literature on the use of reamed locking nail in the treatment of open tibial fractures is limited ${ }^{[13]}$. The criticism that the technique is associated with a high rate of infection and non union largely is based on experimental evidence ${ }^{[16,}$ ${ }^{17]}$ and clinical reports with small number of patients for the most part treated with unlocked reamed nails ${ }^{[18,19]}$. Blachul et al. ${ }^{[20]}$ reported on the use of reamed locking nails to treat 154 closed fractures of tibia and reported a $0 \%$ infection rate. Kaltenecker et al. ${ }^{[21]}$ reported on the use of locking nails to treat 66 Type I and II open tibial fractures and reported a $3.8 \%$ infection rate. Court Brown et al. ${ }^{[22]}$ gave details of the use of the reamed Grosse Kempf nail for 41 grade II and grade III open tibial fractures, reporting an infection in 1 of 14 grade Ii and 3 of 13 grade IIIB fractures. Keating et al. ${ }^{[13]}$ concluded that reamed locking intramedullary interlocking 
nailing is a safe and effective technique for management of open tibial fractures. Kyle ${ }^{[23]}$ reported that reaming did not increase the risk of complications in open tibial fractures. Court Brown et al. ${ }^{[24]}$ stated overall results of the 247 open fractures are comparable to those of external fixation or unreamed nailing, Unreamed nailing has its drawbacks. Although small diameter nails that are inserted without reaming are considered to cause less damage to cortical blood supply. Hupel et al. ${ }^{[25]}$ and Sitter et al. ${ }^{[26]}$ have shown that when such nails are inserted tightly, Prospective randomized studies comparing reamed and un reamed nailing techniques in open tibial fractures have consistently failed to show any difference in infection or union rates but have reported a higher incidence of screw breakage with Unreamed nailing. Blachut et al. ${ }^{[20]}$ in a prospective randomized series in which tibial nailing of closed fractures with reaming was compared with that without reaming, Larsen et al. ${ }^{[27]}$ in their study reported that Unreamed nailing in patients with tibial shaft fractures may be associated with higher rates of secondary operations and malunion compared with reamed nailing. They concluded that reamed nailing is the method of choice in the treatment of displaced, closed, open Type, I, Type II, and Type IIIA central two thirds of tibial shaft fractures.

Reaming allows insertion of larger diameter, stronger nails with larger bolts which produce tight bone implant contact that provide load sharing and resistance to bending or angulation at the fracture site ${ }^{[28]}$. Unreamed small diameter nails, despite interlocking may not provide adequate stability, especially in proximal and distal third fractures and after Dynamization.

Patients were encouraged to move knee and ankle joints on the $1^{\text {st }}$ post operative day after the patient has recovered from anesthesia. Partial weight bearing was delayed till 6 weeks irrespective of the fracture configuration. Full weight bearing was allowed based on clinical and radiological assessment of fracture healing. The average period of commencement of full weight bearing was 12 weeks in the present study. Dynamization allows the fracture site to be compressed during early weight bearing and enhance fracture healing. Dynamization was done in 8 cases by removing either the proximal or distal bolts between 12 and 16 weeks depending on the progress of fracture healing. Templeman et al. ${ }^{[29]}$ in their study performed Dynamization between 6 and 12 weeks. Singer et al. ${ }^{[30]}$ recommended Dynamization between 8 and 12 weeks if the healing in delayed.

The average range of knee joint was 141 degrees. (range 128 - 161 degrees) and that of ankle movements was 84 degrees (range 45-109 degree) in tibial fracture treated by reamed nailing in a study reported by Larsen et al. ${ }^{27}$ Keating et $a l^{13}$ reported a restriction of knee movements in $7 \%$ of cases and loss of ankle motion in $14 \%$ of cases.

\section{Conclusions}

Fracture of tibia represents a complex problem and optimal management is essential if the patient is to regain significant preinjury level of function.

1. Careful preoperative planning and respecting the principles of reamed interlocking nailing technique are essential for obtaining good results.

2. The surgeon should overcome the learning curve for performing intramedullary interlocking nailing.

3. High union rates, low incidence of complications including infection and good functional results suggested that reamed interlocking nailing technique is a satisfactory method of treating closed tibial fractures.
4. Intramedullary interlocking nailing is a safe and effective technique for management of closed tibial fractures. The method is safe and effective in achieving solid union with least number of complications.

5. Most complications following interlocking intramedullary nailing are minor and can be easily treated.

\section{References}

1. Klemm KW, Borner M. Interlocking nailing of complex fractures of femur and tibia. Clin Orthop. 1986; 212:89100.

2. Gustillo RB, Mendoza RM, Williams DN. Problems in the management of Type III (severe) open fractures: A new classification of TypeIII open fractures. J Trauma. 24:742-746.

3. Patzakis MJ, Wilkins J, Moore TM. Considerations in reducing the infection rate in open tibial fractures. Clin Orthop. 1983; 178:36-41.

4. Dellinger EP, Caplan ES, Weaver LD. Duration of preventive antibiotic administration for open extremity fractures. Arch Surg. 198; 123:333-339.

5. Court-Brown CM, Will E, McQueen M. Reamed or unreamed nailing for closed tibial shaft fractures. J Bone Joint Surg. 1996; 78B:580-583.

6. Blick SS, Brumback RJ, Lakotas R, Poka A, Burgess AR. Early prophylactic bone grafting of high energy tibial fractures. Clin Orthop. 1989; 240:21-41.

7. Tornetta P III, Bergman M, Watnik N, Berkowotz G, Steuer G. Treatment of grade IIIB open tibial fractures. A prospective randomized comparison of external fixation and non-reamed locked nailing. J Bone Joint Surg. 1994; 76B:13-19.

8. Holbrook JL, Swiontkowski MF, Sanders R. Treatment of open fractures of the tibial shaft: Ender nailing versus external fixation: A randomized, prospective comparison. J Bone Joint Surg. 1989; 71A:1231-8.

9. Burwell HN. Plate fixation of tibial shaft fractures - A survey of 181 injuries. J Bone and J Surg (Br). 1971; 53:258.

10. Bach AW, Hansen Jr ST. Plates versus external fixation in severe open tibial shaft fractures: A randomized trial. Clin Orthop. 1989; 241:89-94.

11. Velazco A, Whitesides TE, Fleming LL. Open fractures of the tibia treated with the Lottes nail. J Bone Joint Surg. 1983; 65A:879-885.

12. Swanson TV, Speigel JD, Sutherland TB, Bray TJ, Chapman MW. A prospective, comparative study of the Lottes nail versus external fixation in 100 open tibia fractures. Orthop Trans. 1990; 14:716-717.

13. Keating JF, O’Brien PI, Blachut PA, Meek RN, Broekhuyse HM. Reamed interlocking intramedullary nailing of open fractures of tibia. Clin Orthop. 1997; 338:182-191.

14. Keating JF, O'Brien PJ, Blauchut PA, Meek RN, Broekhuyse HM. Locking intramedullary nailing with and without reaming for open fractures of the tibial shaft. A prospective, randomized study. J Bone and Joint Surg. 1997; 79-A:334-41.

15. Henley MB, Chapman JR, Agel J. Treatment of II, IIIA and IIIB open fractures of the tibial shaft: A prospective comparison of unreamed interlocking intramedullary nails and half pin external fixators. J Orthop Trauma. 1998; 12:1-7.

16. Klein MP, Rahn BA, Frigg R, Kessler S, Perren SM. 
Reaming versus non-reaming in medullary nailing: Interference with cortial circulation of the canine tibia. Arch Orthop and Trauma Surg. 1990; 109:314-316.

17. Chapman MW. Principles of intramedullary nailing. In Champman's Operative Orthopaedics, Chapman MW and Madison M (eds), $3^{\text {rd }}$ edition, Philadelphia: Lippincott. 1993: 1:339-353.

18. Bone LB, Johnson KD. Treatment of tibial fractures by reaming and intramedullary nailing. J Bone Joint Surg 1986; 68A:877-87.

19. Hamza KN, Dunkerly GE, Murray MM. Fractures of the tibia-A report on fifty patients treated by intramedullary nailing. J Bone Joint Surg. 1971; 53B: 696-700.

20. Blachut PA, O’Brien PJ, Meek RN, Broekhuyse HM. Interlocking intramedullary nailing with and without reaming for the treatment of closed fractures of the tibial shaft. A prospective, randomized study. J Bone Joint Surg. 1997; 79A:640-646.

21. Kaltenecker G, Wrush O, Quaicoe S. Lower infection rate after interlocking nailing in open fractures of the femur and tibia. J Trauma. 1990; 30: 474-479.

22. Court-Brown CM, McQueen MM, Quaba AA, Christie J. Locked intramedullary nailing of open tibial fractures. J Bone Joint Surg Br. 1991; 73: 959-964.

23. Kyle RF. To ream or not to ream tibial shaft fractures. J Bone Joint Surg. 2002; 84B:227.

24. Court-Brown CM. Reamed intramedullary tibial nailing: An overview and analysis of 1106 cases. J Orthop Trauma. 2004; 18:96-101.

25. Hupel TM, Weinberg JA, Aksenov SA et al. Effects of unreamed, limited reamed, and standard reamed intramedullary nailing on cortical bone porosity and new bone formation. J Orthop Trauma. 2001; 15:18-27.

26. Sitter T, Wilson J, Browner B. The effect of reamed versus unreamed nailing on intramedullary blood supply and cortical viability. J Orthop Trauma. 1990; 4:232.

27. Larsen LB, Madsen JE, Hoiness PR, Ovre S. Should insertion of intramedullary nails for tibial fractures be with or without reaming? A prospective, randomized study with 3.8 years follow up. J Orthop Trauma. 2004; 18:144-149.

28. Finkemeir CG, Schmidt AH, Kyle RF, Templeman DC, Varecka TF. A prospective, randomized study of intramedullary nails inserted with and without reaming for the treatment of open and closed fractures of the tibial shaft. J Orthop Trauma. 2000; 14:187-93.

29. Templeman DC, Benjamin G, Tsukayama DT, Gustilo $\mathrm{RB}$. Update on the management of open fractures of the tibial shaft. Clin Orthop. 1998; 350:18-25.

30. Singer RW, Kellam JF. Open tibial diaphyseal fractures: Results of unreamed locked intramedullary nailing. Clin Orthop. 1995; 315:114-118. 